\title{
Coral bleaching impacts from back-to-back 2015-2016 thermal anomalies in the remote central Indian Ocean
}

\author{
Catherine E. I. Head ${ }^{1,2,5}$ (1) Daniel T. I. Bayley ${ }^{3,4,5} \cdot$ Gwilym Rowlands $^{1}$ •

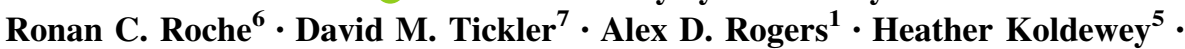 \\ John R. Turner ${ }^{6}$ Dominic A. Andradi-Brown ${ }^{1,8}$
}

Received: 28 September 2018/ Accepted: 20 May 2019/Published online: 12 July 2019

(C) The Author(s) 2019

\begin{abstract}
Studying scleractinian coral bleaching and recovery dynamics in remote, isolated reef systems offers an opportunity to examine impacts of global reef stressors in the absence of local human threats. Reefs in the Chagos Archipelago, central Indian Ocean, suffered severe bleaching and mortality in 2015 following a 7.5 maximum degree heating weeks (DHWs) thermal anomaly, causing a $60 \%$ coral cover decrease from $30 \%$ cover in 2012 to $12 \%$ in April 2016. Mortality was taxon specific, with Porites
\end{abstract}

Topic Editor: Morgan S. Pratchett

Electronic supplementary material The online version of this article (https://doi.org/10.1007/s00338-019-01821-9) contains supplementary material, which is available to authorized users.

Catherine E. I. Head

catherine.head@zoo.ox.ac.uk

1 Department of Zoology, University of Oxford, John Krebs Field Station, Wytham, Oxford OX2 8JQ, UK

2 St Peter's College, New Inn Hall Street, Oxford OX1 2DL, UK

3 Natural History Museum of London, Cromwell Rd, South Kensington, London SW7 5BD, UK

4 Department of Biosciences, University College London, Gower Street, London WC1E 6BT, UK

5 Zoological Society of London, Regent's Park, London NW1 4RY, England, UK

6 School of Ocean Sciences, Bangor University, Menai Bridge, Anglesey LL59 5AB, UK

7 School of Biological Sciences, University of Western Australia, 35 Stirling Highway Crawley, Perth, WA 6009, Australia

8 Ocean Conservation, World Wildlife Fund-US, 1250 24th St. NW, Washington, DC 20037, USA becoming the dominant coral genus post-bleaching because of an $86 \%$ decline in Acropora from 14 to $2 \%$ cover. Spatial heterogeneity in Acropora mortality across the Archipelago was significantly negatively correlated with variation in DHWs and with chlorophyll-a concentrations. In 2016, a 17.6 maximum DHWs thermal anomaly caused further damage, with $68 \%$ of remaining corals bleaching in May 2016, and coral cover further declining by $29 \%$ at Peros Banhos Atoll (northern Chagos Archipelago) from $14 \%$ in March 2016 to $10 \%$ in April 2017. We therefore document back-to-back coral bleaching and mortality events for two successive years in the remote central Indian Ocean. Our results indicate lower coral mortality in 2016 than 2015 despite a more severe thermal anomaly event in 2016. This could be caused by increased thermal resistance and resilience within corals surviving the 2015 thermal anomaly; however, high bleaching prevalence in 2016 suggests there remained a high sensitivity to bleaching. Similar coral mortality and community change were seen in the Chagos Archipelago following the 1998 global bleaching event, from which recovery took $10 \mathrm{yr}$. This relatively rapid recovery suggests high reef resiliency and indicates that the Archipelago's lack of local disturbances will increase the probability that the reefs will again recover over time. However, as the return time between thermal anomaly events becomes shorter, this ability to recover will become increasingly compromised.

Keywords Coral bleaching - Chagos archipelago - Coral mortality · British Indian Ocean Territory · BIOT · Coral community composition 


\section{Introduction}

Coral reefs are experiencing increasing levels of both chronic and acute disturbances, which can cause coral mortality and alter reef community composition, impacting their ability to accrete carbonate and keep pace with sealevel rise (Oliver et al. 2018; Perry et al. 2018). Coral bleaching events associated with thermal anomalies are acute disturbances recognised as the primary global challenge to the persistence of coral reefs (Darling and Cote 2018). Thermal anomalies associated with the El Niño Southern Oscillation (ENSO) are occurring with increasing frequency and severity, driven by anthropogenic climate change (Hughes et al. 2003; Veron et al. 2009), with two sequential events occurring on many reefs between 2014 and 2017 globally (Eakin et al. 2017; Hughes et al. 2017). In particular, the 2016 thermal anomaly surpassed the previous global-scale warming event of 1998 in intensity and duration (Eakin et al. 2017; Oliver et al. 2018).

Coral reef futures now predominantly depend on how scleractinian corals respond to repeated warming events, and if they can adapt to altered climatic conditions. There are several mechanisms by which this may occur: (1) at the level of the coral holobiont, through physiological adaptation, genetic variation, altered Symbiodinium or microbiome composition (Rowan 2004; Roche et al. 2018); (2) through changes in the dominant taxa comprising reefs (Hughes et al. 2003; Berumen and Pratchett 2006); (3) via spatial shifts where reef communities either colonise new areas or remain in limited environmental 'refuge' locations (e.g. Camp et al. 2017). Gathering data on the effects of recurrent bleaching events on coral reefs is critical in assessing the strength and spatial extent of these proposed adaptation mechanisms. The prevalence of such mechanisms, and their relationship with key reef physical and ecological characteristics will determine how coral reef functioning is altered under future climate change, and which reefs are most likely to display resistance or recovery (Holling 1973).

Bleaching is a natural stress response of corals to changes in environmental conditions, including increases in sea temperature (Brown 1997). Bleaching can be divided into two parts: (1) the initial response where corals expel Symbiodinium and (2) the longer-term effect which may be either coral tissue recovery or mortality. The proportion of colonies that bleach represents coral sensitivity, and is a means to assess varying temporal and spatial bleaching impact. Yet in many cases bleaching does not result in coral mortality (Suggett and Smith 2011). Understanding of the relationship between coral bleaching and subsequent mortality is also evolving. Recent evidence suggests that the response to repeated bleaching events, and the ability of coral taxa to acquire resistance to bleaching events, may vary between global ocean regions: reports from the Great Barrier Reef (GBR) of a lack of an adaptive response (Hughes et al. 2017) contrast with those from Kenya indicating a reduction in the severity of response from 1998 to 2016 (McClanahan 2017). There is evidence that recent pre-exposure of corals to higher temperatures can promote resistance to bleaching (Grottoli et al. 2014). However, research on the GBR has shown that future predicted increases in local temperatures of as little at $0.5^{\circ} \mathrm{C}$ may result in this protective mechanism being lost (Ainsworth et al. 2016). At a regional scale, the degree of bleaching response appears spatially consistent between events, with areas that are less susceptible retaining this characteristic in subsequent events (Penin 2013).

Bleaching, and mortality or recovery patterns commonly operate against the background of localised natural and anthropogenic disturbances such as nutrient enrichment, overfishing, and direct human pressure. The nature and extent to which these stressors interact in the processes of bleaching and coral mortality are uncertain (Welle et al. 2017); however, there is some evidence that reef stressors act synergistically (Veron et al. 2009). For example, a reduction in herbivore fish abundance due to overfishing increases algal growth, hence reducing the ability of a reef to recover from bleaching because algal species begin to outcompete recovering corals (Hughes et al. 2007).

Thermal resilience in individual coral colonies is comprised of two key processes: (1) resistance to bleaching and (2) subsequent recovery from bleaching (Mumby et al. 2007; Darling and Cote 2018; Roche et al. 2018). A wide range of factors have been associated with resilience to heat stress, often termed 'resilience indicators' (Obura and Grimsditch 2009; Rowlands et al. 2012; Graham et al. 2015). For instance, higher reef structural complexity has been shown to increase recovery potential (Graham et al. 2015). Wave energy (exposure) increases vertical mixing and associated surface cooling of the water column (Obura and Grimsditch 2009), and some coral hosts are able to increase heterotrophic feeding rates to obtain their daily metabolic energy requirements during bleaching (Grottoli et al. 2006). It is challenging to disentangle the impacts of such factors on reef resilience to thermal anomalies from the effects of local anthropogenic disturbances. It is essential, therefore, to study bleaching impacts on reefs with minimal local human disturbance to enable the effects of global bleaching to be disentangled from interactions with local-scale threats.

The Chagos Archipelago, British Indian Ocean Territory, located in the central Indian Ocean offers an opportunity to examine bleaching dynamics with minimal local human disturbance such as no agricultural runoff, industrial pollution and reef fisheries. The majority of the Chagos 
Archipelago has been uninhabited since the 1970s with the exception of a US military base on one atoll, Diego Garcia, which has strict environmental regulations (Sheppard et al. 2012). As a result, fishing pressure has largely been absent from the Chagos Archipelago since the 1970s, though some illegal harvesting of sea cucumbers (Price et al. 2009) and shark poaching activities are reported (Graham et al. 2010). In 2010, the UK government designated the British Indian Ocean Territory (BIOT) exclusive economic zone (EEZ) a $640,000 \mathrm{~km}^{2}$ marine protected area (MPA), which incorporated the Chagos Archipelago (Sheppard et al. 2012).

In this study, we investigate the effects of the 2015 and 2016 thermal events on reefs surrounding uninhabited Chagos Archipelago atolls. We present data on bleaching patterns and subsequent coral mortality occurring over two successive bleaching events. We also analyse spatial variation in coral mortality across the Archipelago primarily attributed to the 2015 and 2016 bleaching events and use remote sensing data to investigate whether coral mortality is correlated with SSTs, wave exposure, and/or plankton abundance. In the Chagos Archipelago, there is higher productivity on reefs surrounding islands with high seabird populations, whilst reefs surrounding islands with invasive rats, and hence lower seabird populations, have lower productivity (Graham et al. 2018; Ferretti et al. 2018). Nutrient input from seabird guano has been associated with increased plankton populations (McCauley et al. 2012), which could affect coral heterotrophic feeding rates. Wave exposure around the Archipelago differs substantially depending on the orientations of the reefs, with the southeast trade winds blowing from May to September and the north-west trade winds from October to March (Perry et al. 2015). Also the South Equatorial Current (SEC) flows east-west and reverses for a few months a year (Obura 2012). Our results provide crucial insights into the effects of the 2015 and 2016 thermal stress on coral reefs in remote, isolated oceanic islands in the central Indian Ocean.

\section{Materials and methods}

\section{Remote sensing data}

To obtain time series of thermal stress in each survey location, NOAA Coral Reef Watch (2013) Degree Heating Week (DHW) products were sourced at daily $5 \mathrm{~km}$ resolution in NetCDF format. DHW indicates for a given pixel location the accumulation of thermal hotspots greater than $1{ }^{\circ} \mathrm{C}$ relative to the long term climatological mean SST of the hottest month experienced in that pixel. DHW is calculated for a 12-week period preceding a given date. The $5 \mathrm{~km}$ gridded thermal data products do not resolve fully to the shallow water reef face, nor island landmasses, and may be flagged as land. Where this corresponded with the location of one of our survey sites (Fig. 1), the value of the nearest pixel with valid SST data was used.

Surface chlorophyll-a mean values $\left(\mathrm{mg} \mathrm{m}^{-3}\right)$ were extracted for survey sites using Google Earth Engine (Gorelick et al. 2017) for 1 March-15 June 2015 and 15 February-15 April 2016 from the $500 \mathrm{~m}$ resolution Ocean Color SMI: Standard Mapped Image MODIS Aqua Data (NASA Goddard Space Flight Center 2018). Net wave energy $\left(\mathrm{kW} \mathrm{m}^{-1}\right)$ was extracted for survey site coordinates from the Marine Socio-Environmental Covariates database which has calculated mean wave energy to at least $50 \mathrm{~km}^{2}$ spatial resolution from 3-hour temporal resolution for a span of $31 \mathrm{yr}$ (Yeager et al. 2017).

\section{Benthic surveys and image analysis}

Benthic transects were surveyed at 12 survey sites from four atolls-Peros Banhos Atoll, Salomon Atoll, Great Chagos Bank (GCB) Atoll, and Egmont Atoll-across the Chagos Archipelago (Fig. 1) in April 2012 and 2013 and April 2016. Three $30 \mathrm{~m}$ long benthic transects were surveyed per site. In 2012, an Olympus Xz-1 digital camera was used to take a planar benthic image every $0.5 \mathrm{~m}$ along each transect from approximately $0.3 \mathrm{~m}$ height. In 2016 continuous planar video transects were recorded with a Hero4 GoPro holding the camera approximately $0.3 \mathrm{~m}$ above the benthos. All transects were along a continuous transect tape laid parallel to the shoreline at approximately 8-10 $\mathrm{m}$ depth with at least $5 \mathrm{~m}$ separating adjacent transects. Three replicate transects were planned for each survey site, but at one survey site (South Brother within GCB) only two transects were conducted. At one site, Moresby, data were not collected in April 2012 and so were excluded from some of the analysis (figure legends indicate sample size).

In addition to April 2012 and April 2016 surveys, at three sites in north-western Peros Banhos Atoll (Ile Diamant Seaward, Ile Diamant Lagoon, Moresby; Fig. 1), additional benthic transects were also undertaken in March 2016, May 2016 and April 2017 (three transects per site per survey) following the method outlined for April 2016. March 2014 benthic data were also obtained for Ile Diamant Seaward and Moresby from Samoilys et al. (2018). This allowed for a short time-series tracking the bleaching event between 2012 and 2017.

For video transects, still images were extracted every $0.5 \mathrm{~m}$ using VLC software (version 2.2.3; http://www. videolan.org/vlc). Coral Point Count (CPC; Kohler and Gill 2006) was used to analyse images with ten points randomly placed over each image. The benthic taxa or substrate under each point was identified and recorded. Scleractinian 

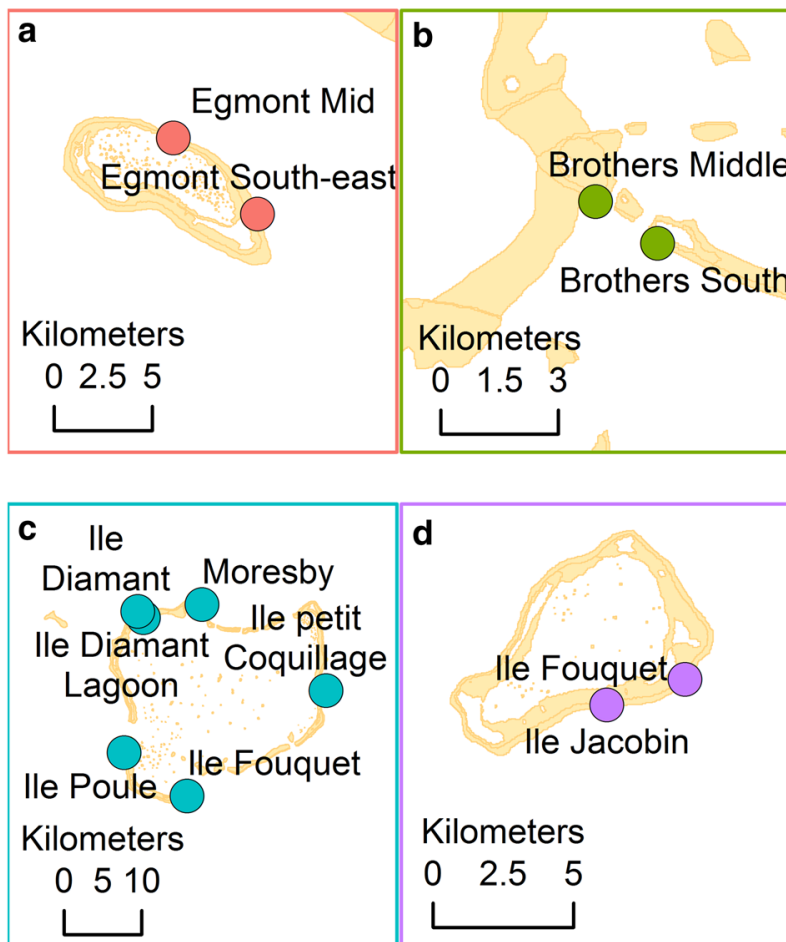

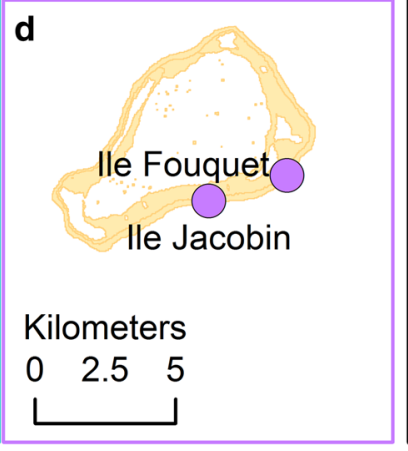

$70^{\circ} 40^{\prime} \mathrm{E}$

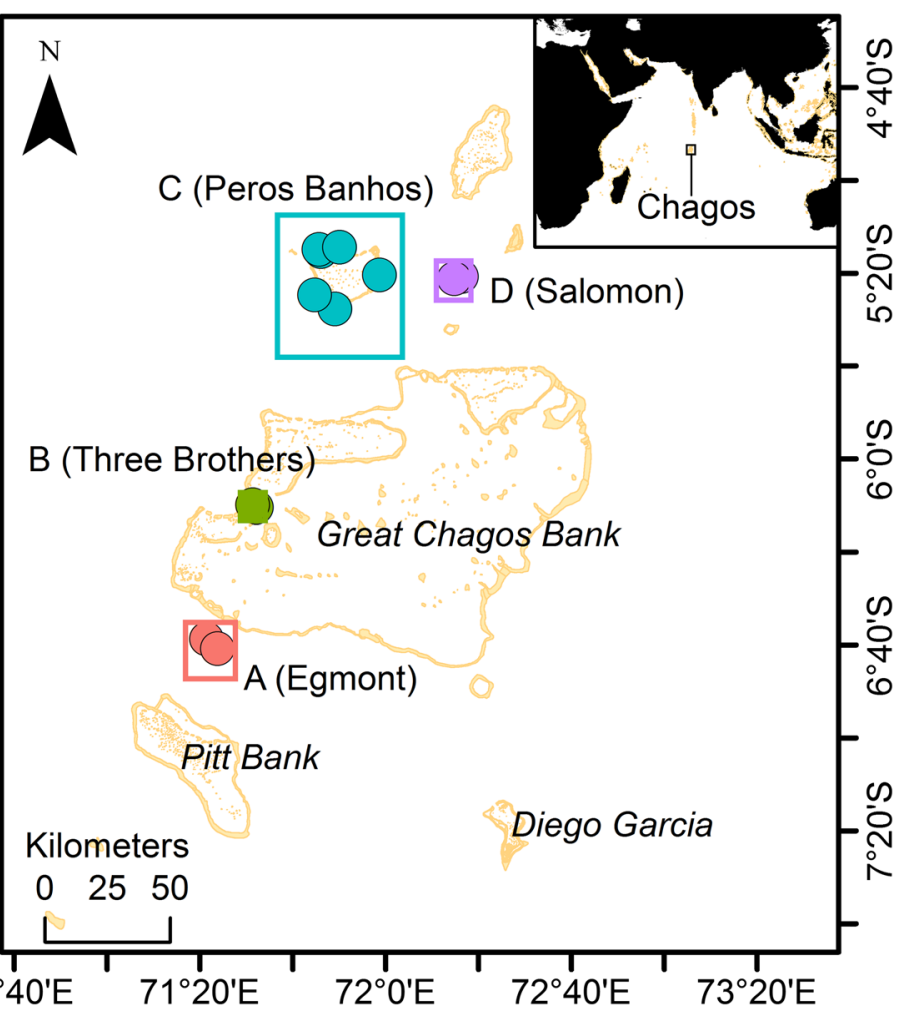

Bank, c Peros Banhos Atoll, d Salomon Atoll. Note colours correspond to colour schemes in Figs. 3 and 5

represent proportions, the logit-link function and binomial family function were used. A GLM was fitted for each dependent variable to the predictor environmental variables and their interactions and then evaluated by comparing the AIC for each model. All models that demonstrated overdispersion (residual deviance higher/lower than degrees of freedom) were fitted with the quasi-family function to introduce a dispersion parameter and obtain a quasi-likelihood estimate (Crawley 2005). Model significance was assessed using $F$-values or Chi-squared values depending on the nature of the dependent variable. The amount of deviance accounted for by the model was calculated using the modEvA package (Barbosa et al. 2014).

One-way repeated measure ANOVAs were used to evaluate the changes through time in the proportion of bleached corals (as a proportion of the total coral cover) and the proportion of healthy coral cover (as a proportion of the total benthic cover) at the three survey sites in Peros Banhos with the time-series 2012-2017. Data were ranktransformed before performing the one-way repeated measure ANOVAs using the nlme package (Pinheiro et al. 2018) because the data are not normally distributed. Data analysis was undertaken in R version 1.1.383 ( $\mathrm{R}$ Development Core Team 2017) and MATLAB version 2018a, 
with results plotted using the ggplot2 package (Wickham 2016).

\section{Results}

\section{Chagos Archipelago reef thermal stress}

The geographic distribution and magnitude of thermal stress in Chagos differed in 2015 compared to 2016 (Fig. 2). In 2015 the Chagos Archipelago experienced a maximum of 7.5 DHW, at the north-western tip of the Great Chagos Bank. Here, conditions were at NOAA Bleaching Alert (https://coralreefwatch.noaa.gov/satellite/ methodology/methodology.php) Level 1 (greater or equal to 4 DHW and less than 8 DHW), where bleaching is considered likely, for a total of 11 weeks between 22 April and 7 July and did not reach Alert Level 2 (greater than 8 DHW), where mortality is considered likely. The thermal anomalies were more extreme in 2016 across the entire archipelago, but greatest in the south-west. Here a maximum of 17.6 DHW was recoded at Pitt Bank. Between 18 March and 21 July, conditions at Pitt Bank were at NOAA Alert Level 1 for 5 weeks and at Level 2 for 13 weeks.

\section{2-2016 Benthic trends}

Live healthy coral cover declined significantly between 2012 and 2016 from $30 \pm 2 \%$ (Mean \pm 1 SE) to $12 \pm 1 \%$, representing a $60 \%$ decrease, across the Chagos Archipelago at the $8-10 \mathrm{~m}$ depth band $(V=292$, $p<0.001$; Table 1 and Fig. 3a). South Brother Island, west GCB, suffered the largest decline from $43 \pm 1$ to $7 \pm 1 \%$ coral cover, representing an $84 \%$ decrease. The eastern side of Egmont Atoll was the only site where coral cover increased from $11 \pm 1 \%$ in 2012 to $14 \pm 1 \%$ in 2016, representing a $27 \%$ increase, but this was not significant $(V=0, p>0.05)$ (Fig. 3).

Acropora and massive Porites together were the most abundant coral genera in Chagos in 2012 comprising 47\% and $34 \%$ of all coral cover, respectively. Acropora cover declined significantly between 2012 and 2016 from $14 \pm 2$ to $2 \pm 1 \%$ of the benthos, representing an $86 \%$ decrease $(V=297, p<0.001$; Fig. 3). Hence, in 2016 Acropora comprised approximately $14 \%$ of coral composition. Cover of Acropora declined in all sites surveyed, with ten of the survey sites exhibiting < 2\% Acropora cover in 2016, including Ile Jacobin and Ile Fouquet (east side of Salomon Atoll) declining to below detectable levels. Ile Diamant lagoon and seaward sites (north-west Peros Banhos) were the only two sites with > 5\% Acropora in April 2016. Massive Porites showed a less uniform pattern across the

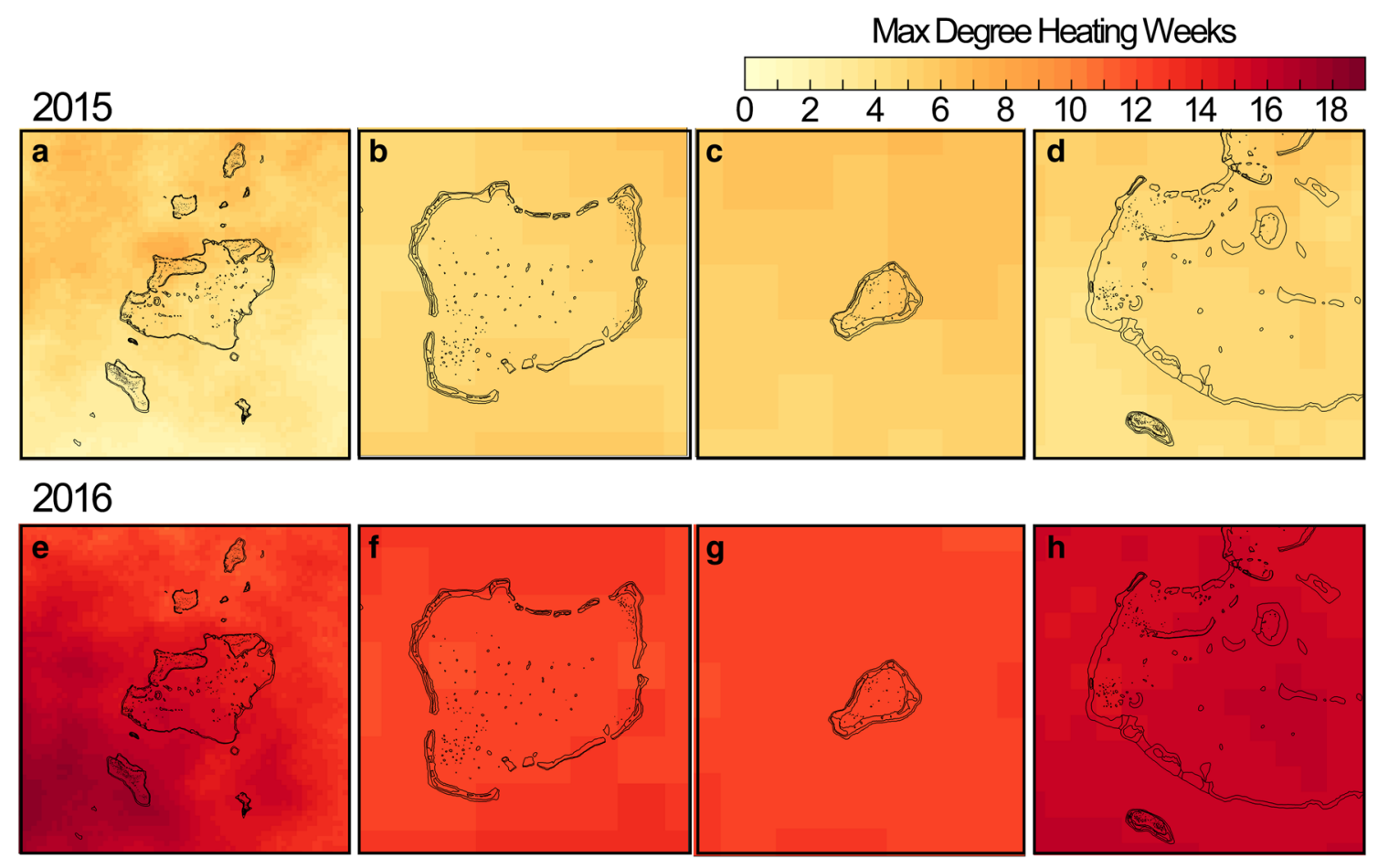

Fig. 2 Heat maps from across the Chagos Archipelago from 1 January-31 December 2015 and 2016 illustrating a-d the maximum DHWs in 2015, and $\mathbf{e}-\mathbf{h}$ the maximum DHWs in 2016. Maps show: a, e whole Chagos Archipelago, b, f Peros Banhos Atoll, c, g Salomon Atoll, and $\mathbf{d}, \mathbf{h}$ the western GCB and Egmont Atoll 
Table 1 Mean changes in per cent benthic cover across the Chagos Archipelago from 2012 to 2016 and results of the Wilcoxon signed-rank test to evaluate the difference in benthic cover between April 2012 and April 2016 across the Archipelago

\begin{tabular}{lcclc}
\hline Benthic category & 2012 mean $(\%) \pm \mathrm{SE}$ & 2016 mean $(\%) \pm \mathrm{SE}$ & Wilcoxon test statistic $(\mathrm{V})$ & $p$ value \\
\hline Mean healthy live coral cover & $30 \pm 2$ & $12 \pm 1$ & 292 & $<0.001^{*}$ \\
Mean healthy Acropora & $14 \pm 2$ & $2 \pm 1$ & 297 & $<0.001^{*}$ \\
Mean healthy Porites & $10 \pm 1$ & $8 \pm 1$ & 206.5 & 0.110 \\
Mean healthy Pocillopora & $2 \pm 1$ & $0.2 \pm 0.3$ & 276 & 26 \\
Mean algae cover & $1 \pm 0.5$ & $4 \pm 0.9$ & 43 & $0.001^{*}$ \\
Mean non-living substrate & $54 \pm 2$ & $68 \pm 2$ & $0.001^{*}$ \\
\hline
\end{tabular}

* Represents a significant result

Archipelago with six survey sites showing a decline, whilst five survey sites showed an increase (Fig. 3). Overall, the trend in massive Porites cover across the Chagos Archipelago from $10 \pm 1 \%$ of the benthos in 2012 to $8 \pm 1 \%$ in 2016 was non-significant ( $V=206.5, p=0.110$; Fig. 3 ). By 2016, because of the Acropora decline, massive Porites became the most dominant coral taxon comprising $65 \%$ of the live coral composition.

Although Pocillopora was not a dominant coral genus in 2012, it still declined significantly. Pocillopora declined from $2 \pm 1 \%$ of the benthos to $<1 \%$ across the Archipelago $(V=276, p<0.001$; Fig. 3$)$. Ile Diamant lagoon (north-west Peros Banhos) and Ile Fouquet and Ile Jacobin (south-east Salomon) all declined to below detectable levels of Pocillopora cover by 2016 (Fig. 3).

Algae cover across the Archipelago (macro-algae, calcareous and turf algae combined) showed a significant increase from 1 to $4 \%$ of the benthos, representing a $75 \%$ increase $(V=26, p=0.002$; Fig. 3). Macro-algae cover decreased from 1 to $<1 \%$ of the benthos, accounting for $99 \%$ of the total algae cover in 2012 but only $4 \%$ of total algae cover in 2016. Substantial heterogeneity was observed within sites and between algae lifeforms, particularly in 2016, with one transect (Ile Petite Coquillage) containing $21 \%$ total algal cover in 2016. However, algal cover was well below $10 \%$ of the benthos in the majority of transects. Across the Archipelago, there was also a significant increase in non-living substrate $(V=43$, $p=0.001$; Fig. 3), concurrent with the decline in coral cover.

\section{Spatial heterogeneity in coral cover change across the Archipelago 2012-2016}

Spatial heterogeneity in coral cover change across the Archipelago (April 2012 to April 2016) was not significantly correlated with 2015 maximum DHWs (GLM, $F=<1, \quad p=0.994$; Fig. 4a), wave energy (GLM, $F=0.161, \quad p \quad$ value $=0.702), \quad$ nor $\quad$ chlorophyll-a concentration (GLM, $F=0.161, p=0.7)$. Mean chlorophyll-a concentrations ranged from $0.125 \mathrm{mg} \mathrm{m}^{-3}$ at Ile Fouquet in Salomon Atoll to $0.275 \mathrm{mg} \mathrm{m}^{-3}$ at South Brothers in GCB (Fig. S1). Mean wave energy ranged from $0.38 \mathrm{~kW} \mathrm{~m}^{-1}$ at Ile Diamant lagoon in Peros Banhos Atoll to $33.74 \mathrm{~kW} \mathrm{~m}^{-1}$ at the south-east site of Egmont Atoll (Fig. S1). DHWs explained $<1 \%$ of the spatial variation in coral cover change across the survey sites, whilst wave energy and chlorophyll-a both explained $2 \%$ of the variation.

Spatial heterogeneity across the Archipelago in Acropora cover change was significantly correlated with maximum DHWs (GLM, $\chi^{2}=22.59, p=<0.05$; Fig. 4c), and chlorophyll-a concentration $\left(G L M, \chi^{2}=6.582, p=<0.01\right)$ but not with wave energy $\left(G L M, \chi^{2}=28.378, p=0.209\right)$. Our GLMs find that maximum DHW patterns explained $19 \%$ of the variation in change in Acropora cover (Fig. 4c), chlorophyll-a concentration explained $15 \%$ and wave energy explained 5\%. Spatial heterogeneity in massive Porites change in cover was not significantly correlated with maximum DHWs $\left(G L M, \chi^{2}=0.14, p=0.708\right.$; Fig. 4e), wave energy (GLM, $\left.\chi^{2}=1.85, p=0.173\right)$, or chlorophyll-a concentration $\left(G L M, \chi^{2}=1.182, p=0.277\right)$, but there was a significant interaction between maximum DHWs, mean wave energy and chlorophyll-a concentration (GLM, $\left.\chi^{2}=6.583, p=0.01\right)$. This significant interaction may be a result of the effect of wave energy on water mixing which would likely impact sea surface temperatures and chlorophyll-a concentrations. DHWs explained $<1 \%$ of the Porites heterogeneity across the survey sites, with wave energy explaining $14 \%$ and chlorophyll-a explaining $<2 \%$ of the heterogeneity.

\section{6-2017 Further coral bleaching and mortality}

We surveyed three sites in north-west Peros Banhos Atoll in April 2012, March, April, and May 2016, and April 2017. The change in the relative abundance of bleached coral colonies (as a proportion of total coral cover) through 
Fig. 3 The change in benthic composition from April 2012 to April 2016 across all survey sites, summarised by atoll $(\mathrm{EG}=$ Egmont, $\mathrm{GCB}=$ Great Chagos Bank, PB = Peros Banhos, $\mathrm{SA}=$ Salomon) in: a total live healthy coral cover, b non-living substrate, c live healthy massive Porites sp. coverage, $\mathbf{d}$ live healthy Acropora sp. coverage, e live healthy Pocillopora sp. coverage, $\mathbf{f}$ algae coverage. 'Live coral' refers to nonbleached live coral
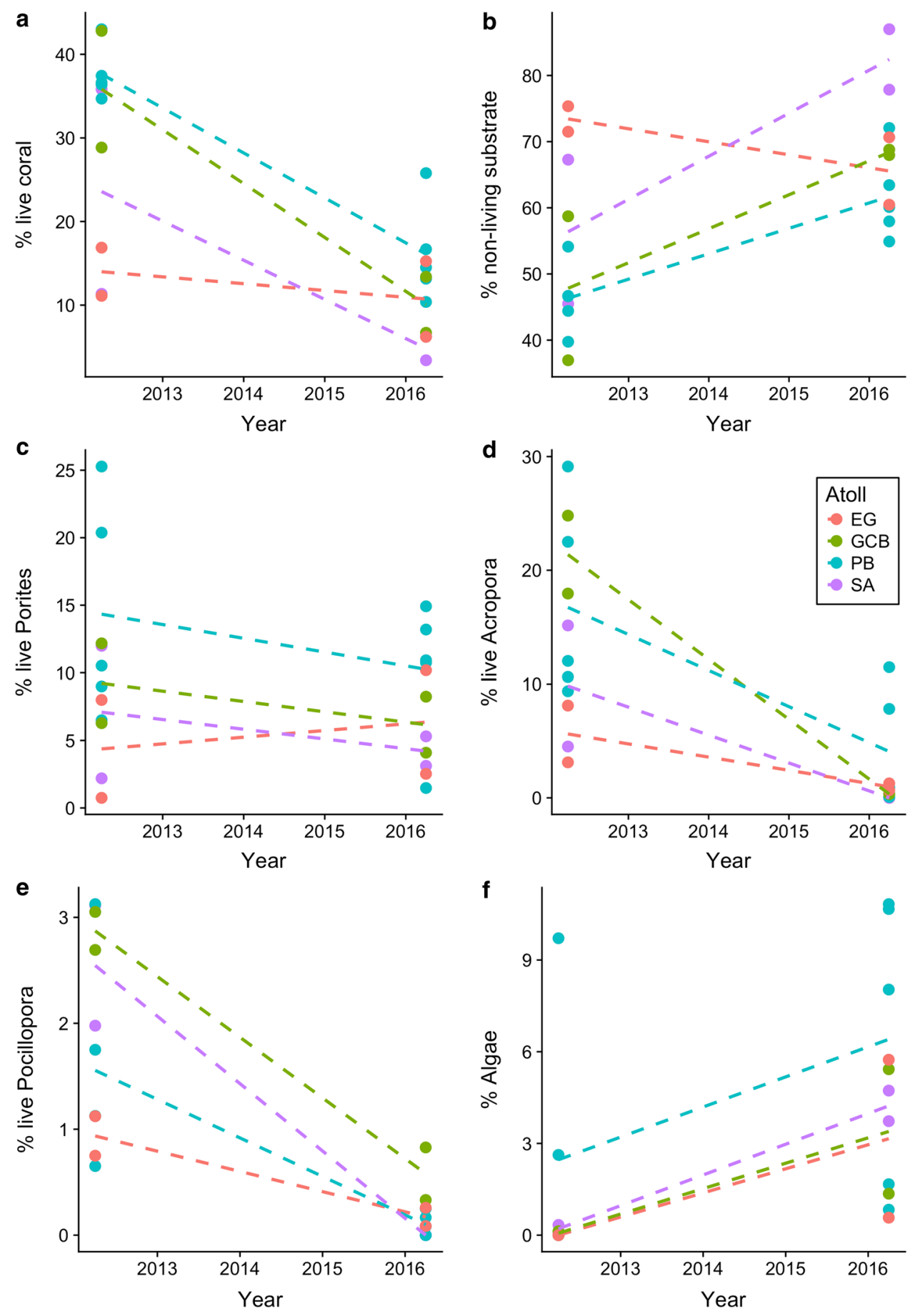

time was significant $(F=8.03, p=0.016)$, with bleached colonies observed during all surveys in 2016 and 2017. We identified an increase in the proportion of bleached corals from March $2016(11 \pm 4 \%)$ through April 2016 (24 $\pm 9 \%)$ to May 2016 (68 $\pm 6 \%$; Fig. 5a, Table 2). This correlates with the increase in maximum degree heating weeks (DHWs) for the area from 4 DHWs on 22 March 2016 to 15 DHWs on 15th May 2016, the day of our final 2016 assessment (Fig. 5). Surveys conducted in April 2017 showed the proportion of bleached colonies to be $10 \pm 6 \%$. Whilst this detailed time series is restricted to the three north-west Peros Banhos sites, in 2016 bleaching appeared to be widespread in Chagos. Our surveys of 11 sites in April 2016, before peak DHWs were reached for 2016 , identified $4 \pm 2 \%$ bleached coral cover.

The trend in healthy coral cover (as a proportion of total benthic cover) through time was also significant $(F=16.63, p=0.003)$. Healthy coral cover reduced from 

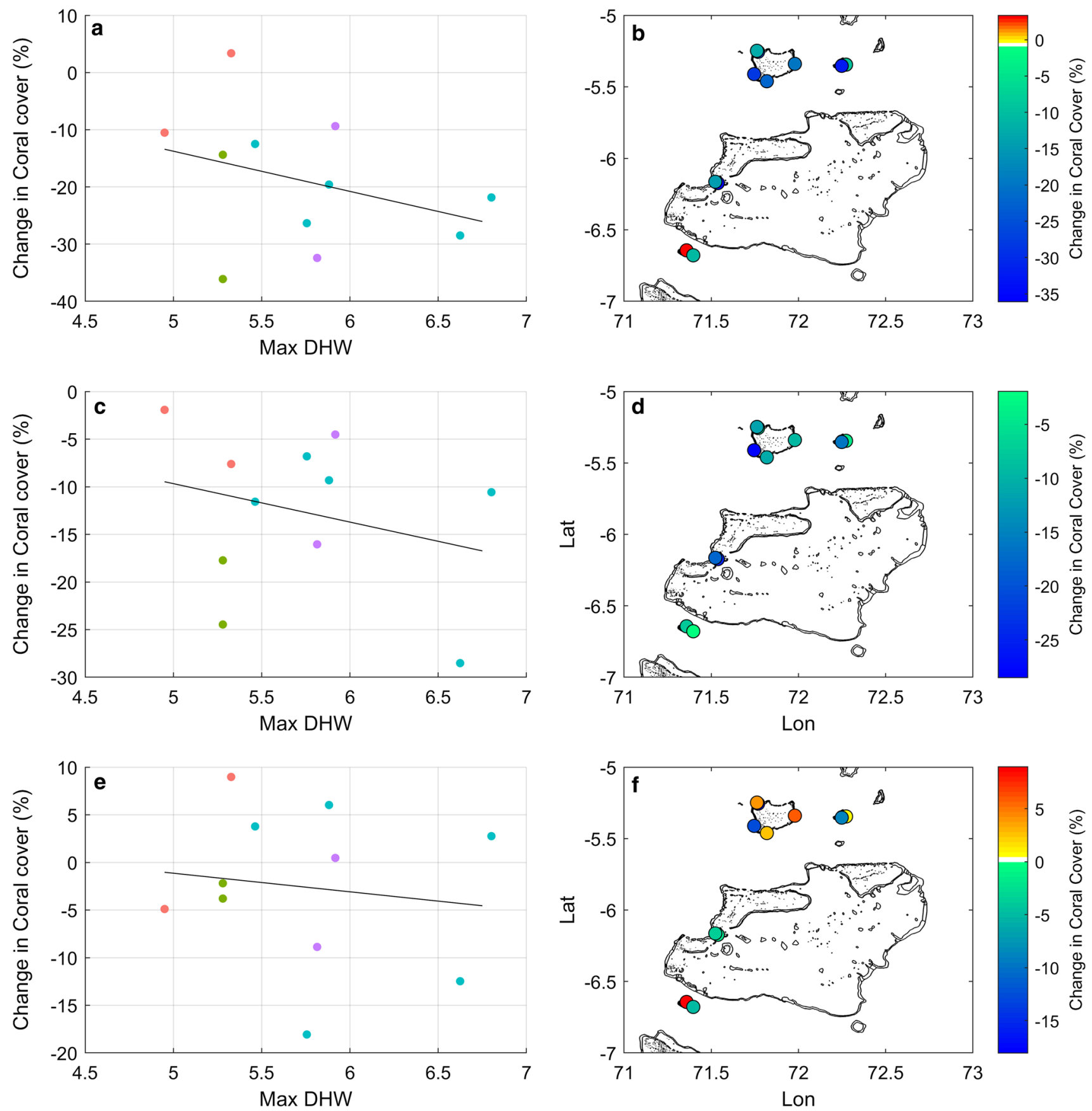

Fig. 4 Relationship between maximum DHWs (March 2012-April 2016) and the change in coral cover (April 2012-April 2016) for each site. $(\mathbf{a}, \mathbf{b})$ Total coral cover, $(\mathbf{c}, \mathbf{d})$ Acropora sp. cover, (e, f) Porites sp. cover. For a, c, e colours correspond to atolls as illustrated in

Fig. 1 (red = Egmont, blue $=$ Peros Banhos, purple = Salomon, green $=\mathrm{GCB})$. For $(\mathbf{b}, \mathbf{d}, \mathbf{f})$, maps illustrate the spatial variation in coral cover change between April 2012-April 2016

$14 \pm 3 \%$ in March 2016 to a low of $5 \pm 1 \%$ in May 2016, before increasing to $10 \pm 2 \%$ in April 2017 (Table 2 and Fig. 5b), suggesting some recovery from the 2016 bleaching but an overall decline of $29 \%$.

\section{Discussion}

Our results show that during the period 2012-2017 there was significant widespread severe loss of hard coral cover in the Chagos Archipelago, which occurred in at least two distinct events correlated with peaks in DHWs in 2015 and 2016. During this time, hard coral communities on reefs 
Fig. 5 Trends in coral health and cover and associated degree heating weeks (DHWs) for three sites in north-west Peros Banhos. Peaks show the DHWs corresponding to temperature anomalies in 2015 and 2016 for the three sites $(n=3)$. a The lines represent cover of bleached, diseased, and healthy coral as a percentage of total coral cover, and $\mathbf{b}$ live healthy coral cover and all coral (healthy, bleached, and diseased) as a percentage of total benthic cover, in April 2012, April 2014, March 2016, April 2016, May 2016, and April 2017
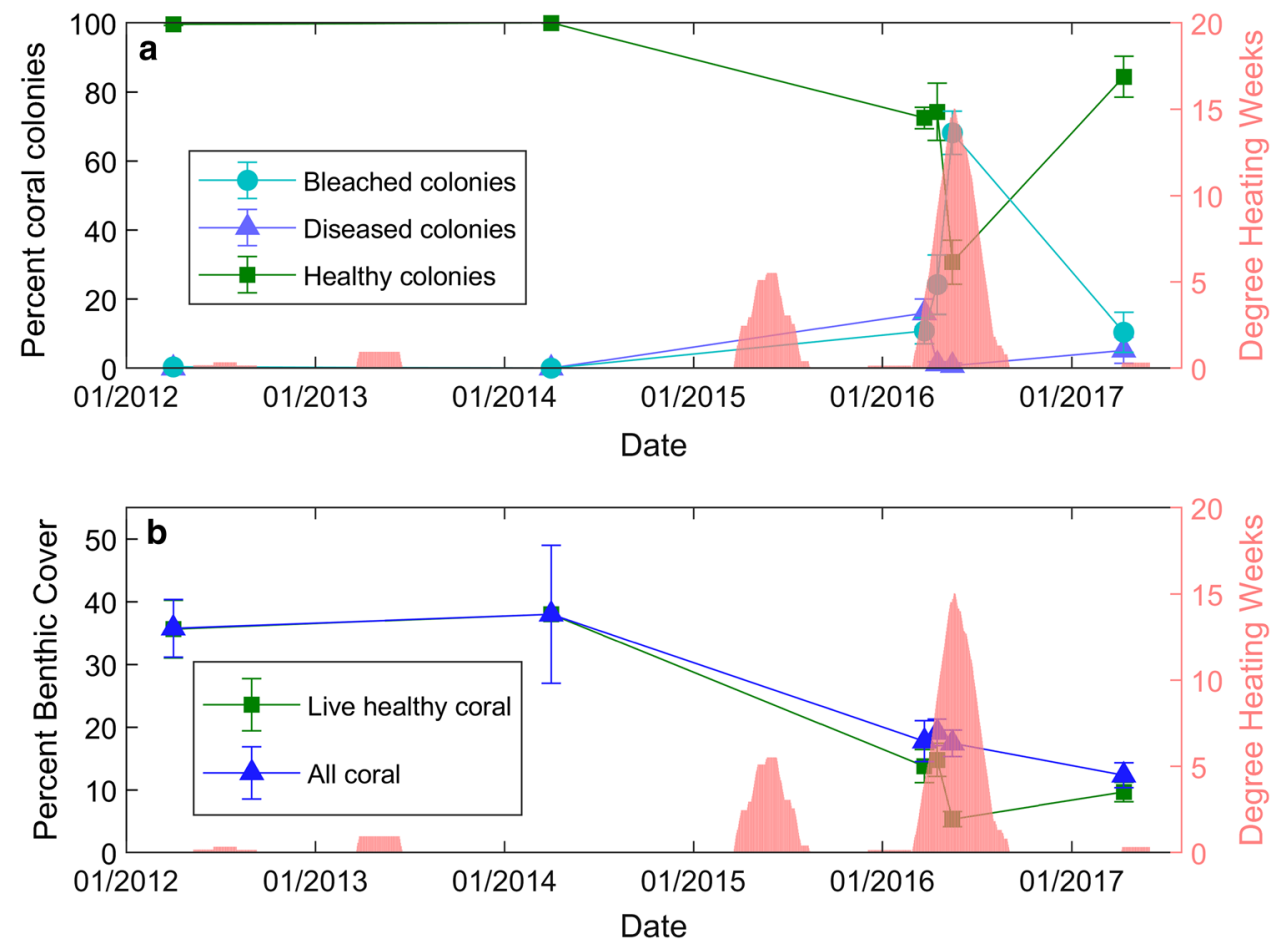

Table 2 Trends in the mean bleached coral as proportion of live coral cover, and in mean healthy corals as a proportion of the benthic cover at three sites at Peros Banhos Atoll in March, April, and May 2016

\begin{tabular}{|c|c|c|c|c|c|c|}
\hline Benthic category & $\begin{array}{l}\text { March } 2016 \text { mean } \\
(\%) \pm \mathrm{SE}\end{array}$ & $\begin{array}{l}\text { April } 2016 \text { mean } \\
(\%) \pm \mathrm{SE}\end{array}$ & $\begin{array}{l}\text { May } 2016 \text { mean } \\
(\%) \pm \mathrm{SE}\end{array}$ & $\begin{array}{l}\text { April } 2017 \text { mean } \\
(\%) \pm \mathrm{SE}\end{array}$ & $\begin{array}{l}\text { ANOVA } \\
(F \text { statistic })\end{array}$ & $p$ value \\
\hline $\begin{array}{l}\text { Mean bleached corals as } \% \\
\text { of live coral }\end{array}$ & $11 \pm 4$ & $24 \pm 9$ & $68 \pm 6$ & $10 \pm 6$ & 8.03 & $0.016^{*}$ \\
\hline $\begin{array}{l}\text { Mean healthy corals as \% of } \\
\text { the benthos }\end{array}$ & $14 \pm 3$ & $15 \pm 2$ & $5 \pm 1$ & $10 \pm 2$ & 16.63 & $0.003^{*}$ \\
\hline
\end{tabular}

*Represents a significant result

within the Archipelago shifted from being Acroporadominated to massive Porites-dominated, because of high Acropora mortality. Our results are consistent with the global impacts of coral bleaching reported over the same period (Eakin et al. 2017, Hughes et al. 2018, Claar et al. 2018) in response to increases in SSTs as a result of an ENSO climatic event which originated in the Pacific in 2014 (Couch et al. 2017).

The significant correlation between spatial variation in Acropora decline and DHWs provides evidence that the peaks in water temperature in March-June 2015 and 2016 were the predominant cause of the recorded coral mortality. No other severe peaks in DHWs were recorded in Chagos between our 2012 baseline data and early 2015 (Fig. 5). Surveys conducted in the Chagos Archipelago in April 2015 recorded $>40 \%$ healthy coral cover, whilst surveys conducted in May 2015 observed approximately and April 2017. Results of the one-way repeated measure ANOVAs to evaluate changes in the two benthic categories through time 
Fig. 6 Extensively bleached Acropora spp. at Ile Diamant Seaward site, Peros Banhos Atoll, in May 2016

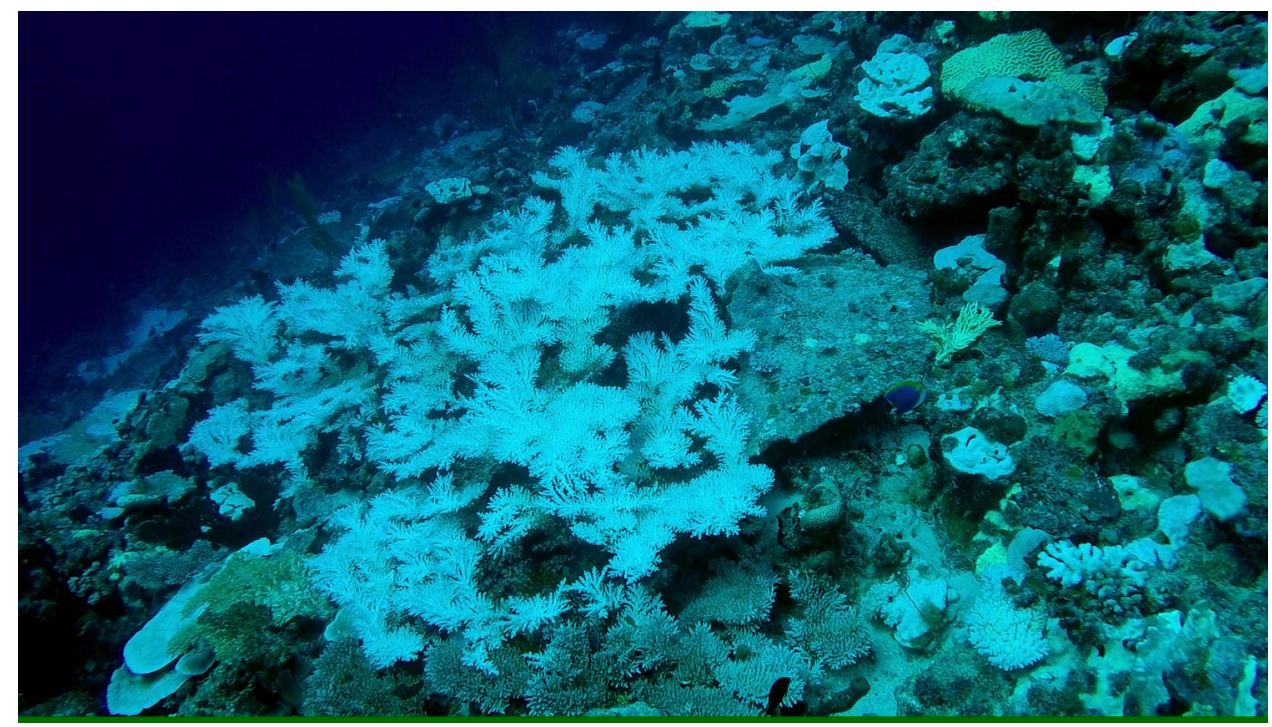

Mechanisms behind thermal resilience need further investigation but may include thermal adaptations through physiological and genetic variation of the coral hosts, the dinoflagellate algae and associated microorganisms, and/or through community change (Roche et al. 2018). At two fully protected Kenyan marine reserves McClanahan (2017) reported a reduction in sensitivity to bleaching in coral taxa, including Acropora and Porites, between two bleaching events (1998 and 2016). A similar pattern has also been reported in Moorea between bleaching events in 2002 and 2007 (Penin 2013). In contrast, on the Great Barrier Reef exposure to bleaching in 1998 and 2002 did not lessen the severity of bleaching in 2016 (Hughes et al. 2017). Within the Chagos Archipelago, a high proportion of corals bleached in 2016 (72\%), but it is not possible to quantitatively compare this to the proportion of bleaching in 2015 or in previous years to assess whether past exposure has lessened sensitivity to bleaching. However, there was less coral mortality following the 2016 temperature anomaly, compared to coral mortality levels recorded after the 2015 temperature anomaly. This is possibly due to past exposure to temperature anomalies in 2015 creating a more thermally resilient coral population. Coral community change is a likely mechanism behind this reduction in mortality because a significant proportion of the more thermally susceptible taxa (Darling et al. 2012), e.g. Acropora and Pocillopora, had suffered high mortality rates after the 2015 bleaching event. Nevertheless, the increases in DHWs (17.6 max DHWs in south-west) in 2016 did cause bleaching and subsequent mortality, albeit at lower levels.

The pattern of bleaching and mortality in the Chagos Archipelago can be compared with other locations in the Indian Ocean, where the most severe bleaching impacts appear to have occurred in 2016 (McClanahan 2017). For example, in the Maldives, a similar oceanic atoll reef system in the northern Indian Ocean, the greatest thermal stress was also experienced by reefs during May 2016 (Perry and Morgan 2017a). This resulted in mean coral cover declines from 26\% in January 2016 to $6 \%$ in September 2016 (Perry and Morgan 2017a). In the Chagos Archipelago, mean coral cover levels in April 2016 were already down to $12 \%$ before 2016 bleaching began, likely a result of the 2015 bleaching event, although high levels of background mortality and disease within tabular Acropora were consistently observed following the 1998 bleaching event (Pratchett et al. 2010, 2013). Similar proportions of corals in north-west Peros Banhos Atoll (Chagos Archipelago) bleached in 2016 (68\% in May 2016) as in the Maldives during the peak of bleaching (77\% in May-June 2016; Ibrahim et al. 2017). Following the Maldivian reef bleaching, in March 2017 many sub-massive and compact branched colonies that had originally survived began to show partial mortality (Perry and Morgan 2017b).

The spatial heterogeneity in coral cover decline across the four atolls in the Chagos Archipelago which was not attributed to spatial variation in DHWs may be due to other interacting environmental factors and the corals' physiological and genetic characteristics. An individual coral colony's susceptibility to stress and bleaching is known to be highly variable as a result of eco-physiological and genetic adaptations (Coles and Brown 2003; Weis 2008). Environmental variables also play a part, and here we tested whether wave energy or plankton availability (using chlorophyll-a as a proxy) were drivers of spatial variation in coral decline. Chlorophyll-a concentrations were significantly directly correlated with the spatial heterogeneity in Acropora cover decline. Spatial variability in plankton 
availability as a food source for heterotrophic feeding has been shown to explain variation in coral trophic ecology (Fox et al. 2018), and some coral species can increase heterotrophic feeding to meet metabolic needs (Grottoli et al. 2006). However, rather than suggesting that higher plankton availability may lead to higher coral survivorship during bleaching, our results suggest that chlorophyll-a concentrations are correlated with an increase in coral decline-although the heterogeneity in chlorophyll-a concentrations is low $\left(0.125-0.274 \mathrm{mg} \mathrm{m}^{-3}\right)$ across the Archipelago and hence may not be meaningful. In contrast, wave energy was not found to be a significant driver of spatial heterogeneity in coral cover decline. Increases in wave energy can result in water column mixing and cooling and flushing of the benthic boundary layer (Obura and Grimsditch 2009), but its effect depends on the depth of mixing resulting from the waves and the depth of the thermocline. It is probable that these variables would need to be more closely measured through in-water instrumentation at a closer proximity to each reef than through existing remote sensing methods. Interestingly Safaie et al. (2018) recently found high-frequency temperature variability (i.e. daily temperature range) to be the largest predictor of bleaching prevalence globally. Within the Chagos Archipelago, localised daily temperature plunges of between 5 and $7{ }^{\circ} \mathrm{C}$ at frequencies of $1-4 \mathrm{~d}$, thought to be driven by upwelling of cooler water as a result of internal wave formation, have been recorded at some locations (Sheppard 2009) and may further explain the spatially heterogeneous patterns in coral mortality.

Whilst this study documents geographically widespread severe declines in coral cover on reefs at approximately $10 \mathrm{~m}$ depth, bleaching mortality was not equal across depth. Our quantitative diver surveys were limited to shallow reefs because of the remoteness of the Chagos Archipelago, but during April 2016 and April 2017 brief observations were also made to $25 \mathrm{~m}$ depth. On reefs below approximately $15 \mathrm{~m}$, coral mortality from bleaching was reduced (Sheppard et al. 2017). During April 2016, remote-operated vehicle surveys were also conducted in the Chagos Archipelago of upper mesophotic coral ecosystems (MCEs) between 30 and $60 \mathrm{~m}$ depth (AndradiBrown et al. 2019). Although there is a limited historical baseline to compare these deeper surveys to, these surveys suggested that at least some MCE sites may have been minimally affected by the 2015 bleaching event and so maintained crucial biodiversity and fish habitat. For example, MCE reefs at Ile Anglaise, Salmon Atoll, in the $35-45 \mathrm{~m}$ depth range, had close to $100 \%$ live Pachyseris speciosa cover, with no evidence of bleaching when surveyed in April 2016 (Andradi-Brown et al. 2019).

Reefs of the Chagos Archipelago recovered from severe bleaching following the 1998 global coral bleaching event with coral cover back to pre-1998 levels by 2010 and a canopy cover of coral observed by 2006 (Sheppard et al. 2012). The SSTs in 1998 rose by a mean of $1{ }^{\circ} \mathrm{C}$ over 2 months, and coral cover around the Archipelago fell from $50-70 \%$ (1996) to $\sim 10 \%$ on shallow $(5-10 \mathrm{~m})$ outer reefs (1999) (Sheppard 1999). Massive Porites accounted for approximately $80 \%$ of this remaining live coral cover in 1999, whilst Acropora table corals were recorded as nearly completely absent (Sheppard 1999). This level of coral cover post-bleaching and the composition of Acropora and Porites are very similar to the results we report from the 2015 and 2016 bleaching. After the mortality caused by the 1998 bleaching event signs of recovery were observed from surveys 3 yr after the event, with coral recruits recorded at densities of $28 \mathrm{~m}^{2}$, the highest recorded globally at the time (Sheppard 2002; Harris and Sheppard 2008). Sheppard et al. (2017) report lower densities of coral recruits in April 2017, $1 \mathrm{yr}$ on from the 2016 bleaching, but the levels are still high in comparison to records from other locations (Cowburn et al. 2018; Turner et al. 2018). Also, modelling studies have predicted good vertical and horizontal larval connectivity in the Chagos Archipelago, which would facilitate coral recruitment and subsequent reef recovery (Riegl and Piller 2003). Mean algae cover remained low in 2016 surveys at $4 \%$, consistent with a high herbivorous fish biomass (Graham et al. 2013) reducing algal growth and allowing coral recruits the space to recolonise the reef.

In summary, coral mortality attributed mainly to the 2015/2016 bleaching events has been severe in the Chagos Archipelago, and similar to that reported in many other locations globally (Hughes et al. 2017; Eakin et al. 2017; Couch et al. 2017; Claar et al. 2018). This shows that the remoteness of the Archipelago and its protected nature, which safeguards the reefs from most direct human impacts, does not provide it with resistance to bleaching and subsequent mortality. However, the Chagos Archipelago recovered well from the 1998 bleaching event, when coral mortality rates were similar to those seen in back-toback 2015/2016 event reported here. This evidence of historic resilience plus reasonable coral recruitment levels, high coral cover in MCEs and high herbivorous fish biomass make for an optimistic outlook for recovery within the Archipelago. However, the longer-term outlook for reefs of the Chagos Archipelago depends on their ability to maintain resilience to the increasingly frequent and severe thermal anomalies predicted as a consequence of accelerating global climate change.

Acknowledgements This work was supported by the Bertarelli Foundation as part of the Bertarelli Programme in Marine Science (Chagos Science Expedition 2016 and 2017, and CEIH PDRA position), UK Natural Environment Research Council (NERC) for CASE studentship awards and Zoological Society of London for CASE partnership (NERC grant reference: NE/1018298/1 for CEIH an NE/ 
L002485/1 for DTIB), Selfridges' Project Ocean Fund (Chagos Science Expedition 2012), the Darwin Initiative (DI reference: 19-027, Chagos Science Expedition 2013 and 2014) and Fisheries Society of the British Isles (DAAB PhD studentship). We thank Professor Charles Sheppard for expedition leadership (2012); Pascaline Cotte, the Pacific Marlin, and Grampian Frontier crews for assistance with fieldwork; and Rachel Jones, Emma Levy, and The Bertarelli Foundation for logistical coordination.

\section{Compliance with ethical standards}

Conflict of interest On behalf of all authors, the corresponding author states that there is no conflict of interest.

Open Access This article is distributed under the terms of the Creative Commons Attribution 4.0 International License (http://crea tivecommons.org/licenses/by/4.0/), which permits unrestricted use, distribution, and reproduction in any medium, provided you give appropriate credit to the original author(s) and the source, provide a link to the Creative Commons license, and indicate if changes were made.

\section{References}

Ainsworth TD, Heron SF, Ortiz JC, Mumby PJ, Grech A, Ogawa D, Eakin MC, Leggat W (2016) Climate change disables coral bleaching protection on the Great Barrier Reef. Science 352(6283):338-341

Andradi-Brown DA, Dinesen Z, Head CEI, Tickler DM, Rowlands G, Rogers AD (2019) The Chagos Archipelago. In: Loya Y, Puglise KA, Bridge T (eds) Mesophotic coral ecosystems, coral reefs of the world. Springer, New York, pp 215-230. https://doi.org/10. 1007/978-3-319-92735-0_12

Barbosa AM, Brown JA, Jiménez-Valverde A, Real R (2014) modEvA - Model Evaluation and Analysis. R package, version $1(3): 2$

Berumen ML, Pratchett MS (2006) Recovery without resilience: persistent disturbance and long-term shifts in the structure of fish and coral communities at Tiahura reef. Moorea. Coral Reefs 25(4):647-653. https://doi.org/10.1007/s00338-006-0145-2

Brown BE (1997) Coral bleaching: causes and consequences. Coral Reefs. 16:129-138. https://doi.org/10.1007/s003380050249

Camp EF, Nitschke MR, Rodolfo-Metalpa R, Houlbreque F, Gardner SG, Smith DJ, Zampighi M, Suggett DJ (2017) Reef-building corals thrive within hot-acidified and deoxygenated waters. Scientific Reports 7(1):2434. https://doi.org/10.1038/s41598017-02383-y

Cinner JE, Huchery C, MacNeil MA, Graham NAJ, McClanahan TR, Maina J, Maire Eva, Kittinger JN, Hicks CC, Mora C, Allison EH, D'Agata S, Hoey A, Feary DA, Crowder L, Williams ID, Kulbicki M, Vigliola L, Wantiez L, Edgar G, Stuart-Smith RD, Sandin SA, Green AL, Hardt MJ, Beger M, Friedlander A, Campbell SJ, Holmes KE, Wilson SK, Brokovich E, Brooks AJ, Cruz-Motta JJ, Booth DJ, Chabanet P, Gough C, Tupper M, Ferse SCA, Sumaila UR, Mouillot D (2016) Bright spots among the world's coral reefs. Nature 353:416-419

Claar DC, Szostek L, McDevitt-Irwin JM, Schanze JJ, Baum JK (2018) Global patterns and impacts of El Niño events on coral reefs: A meta-analysis. PLoS ONE 13(2):e0190957. https://doi. org/10.1371/journal.pone.0190957

Coles SL, Brown BE (2003) Coral bleaching — capacity for acclimatization and adaptation. Adv Mar Biol 46:183-223. https://doi. org/10.1016/S0065-2881(03)46004-5
Couch CS, Burns JHR, Liu G, Steward K, Gutlay TN, Kenyon J, Eakin MC, Kosaki RK (2017) Mass coral bleaching due to unprecedented marine heatwave in Papahānaumokuākea Marine National Monument (Northwestern Hawaiian Islands). PLoS ONE 12(9):e0185121. https://doi.org/10.1371/journal.pone. 0185121

Cowburn B, Samoilys MA, Obura D (2018) The current status of coral reefs and their vulnerability to climate change and multiple human stresses in the Comoros Archipelago, Western Indian Ocean. Marine Pollution Bulletin 133:956-969

Crawley M (2005) The R Book. Wiley, Chichester

Darling ES, Cote IM (2018) Seeking resilience in marine ecosystems. Science 359(6379):986-987. https://doi.org/10.1126/science. aas 9852

Darling ES, Alvarez-Filip L, Oliver TA, McClanahan TR, Cote MI (2012) Evaluation life-history strategies of reef corals from species traits. Ecol Lett 15(12):1378-1386. https://doi.org/10. 1111/j.1461-0248.2012.01861.x

Eakin CM, Liu G, Gomez AM, De La Cour JL, Heron SF, Skirving WJ, Geiger EF, March BL, Tirak KV, Strong AE (2017) Ding, dong, The witch is dead (?) - three years of global coral bleaching 2014-2017. Reef Encounter 45:33-38

Ferretti F, Curnick D, Liu K, Romanov E, Block B (2018) Shark baselines and the conservation role of remote coral reef ecosystems. Science Advances 4(3):eaaq0333

Fox M, Williams G, Johnson M, Radice V, Zgliczynski BJ, Kelly E, Rohwer F, Sandin SA, Smith J (2018) Gradients in primary production predict trophic strategies of mixotrophic corals across spatial scales. Current Biology. https://doi.org/10.1016/j.cub. 2018.08.057

Gorelick N, Hancher M, Dixon M, Ilyushchenko S, Thau D, Moore R (2017) Google Earth Engine: Planetary-scale geospatial analysis for everyone. Remote Sensing of Environment 202:18-27

Graham NAJ, Spalding MD, Sheppard CRC (2010) Reef shark declines in remote atolls highlight the need for multi-faceted conservation action. Aquatic Conservation: Marine and Freshwater Ecosystems 20:543-548

Graham NAJ, Pratchett MS, McClanahan TR, Wilson SK (2013) The status of coral reef assemblages in the Chagos Archipelago, with implications for protected area management and climate change. In: Sheppard CRC (ed) Coral Reefs of the United Kingdom Overseas Territories. Coral Reefs of the World, 4. Springer, Dordrecht, pp 253-270

Graham NAJ, Jennings S, MacNeil MA, Mouillot D, Wilson SK (2015) Predicting climate-driven regime shifts versus rebound potential in coral reefs. Nature 00:1-17

Graham NAJ, Wilson SK, Carr P, Hoey AS, Jennings S, MacNeil MA (2018) Seabirds enhance coral reef productivity and functioning in the absence of invasive rats. Nature 559:250-253. https://doi. org/10.1038/s41586-018-0202-3

Grottoli AG, Rodrigues LJ, Palardy JE (2006) Heterotrophic plasticity and resilience in bleached corals. Nature 440:1186-1189

Grottoli AG, Warner ME, Levas SJ, Aschaffenburg MD, Schoepf V, McGinley M et al (2014) The cumulative impact of annual coral bleaching can turn some coral species winners into losers. Global Change Biology 20(12):3823-3833. https://doi.org/10.1111/gcb. 12658

Harris A, Sheppard CRC (2008) Status and recovery of the coral reefs of the Chagos Archipelago, British Indian Ocean Territory. In: Obura D, Souter D, Linden O (eds) Indian Ocean Coral Reefs. Kalmar University, CORDIO, pp 61-69

Holling CS (1973) Resilience and Stability of Ecological Systems. Annual review of Ecology and Systematics 4:1-23. https://doi. org/10.1146/annurev.es.04.110173.000245

Hughes TP, Baird AH, Bellwood DR, Card M, Connolly SR, Folke C, Grosberg R, Hoegh-Guldberg O, Jackson JB, Kleypas J, Lough 
JM, Marshall P, Nyström M, Palumbi SR, Pandolfi JM, Rosen B, Roughgarden J (2003) Climate change, human impacts, and the resilience of coral reefs. Science 301(5635):929-933

Hughes TP, Rodrigues MJ, Bellwood DR, Ceccarelli D, HoeghGuldberg O, McCook L, Moltschaniwskyji N, Pratchett MS, Steneck RS, Willis B (2007) Phase shifts, herbivory, and the resilience of coral reefs to climate change. Current Biology 17:360-365

Hughes TP, Kerry JT, Álvarez-Noriega M, Álvarez-Romero JG, Anderson KD, Baird AH, Babcock RC, Beger M, Bellwood DR, Berkelmans R, Bridge TC, Butler IR, Byrne M, Cantin NE, Comeau S, Connolly SR, Cumming GS, Dalton SJ, Diaz-Pulido G, Eakin CM, Figueira WF, Gilmour JP, Harrison HB, Heron SF, Hoey AS, Hobbs JPA, Hoogenboom MO, Kennedy EV, Kuo C, Lough JM, Lowe RJ, Liu G, McCulloch MT, Malcolm HA, McWilliam MJ, Pandolfi JM, Pears RJ, Pratchett MS, Schoepf V, Simpson T, Skirving WJ, Sommer B, Torda G, Wachenfeld DR, Willis BL, Wilson SK (2017) Global warming and recurrent mass bleaching of coral. Nature 543:373-377

Hughes TP, Kerry JT, Baird AH, Connolly SR, Dietzel A, Eakin MC, Heron SF, Hoey AS, Hoogenboom MO, Liu G, McWilliam MJ, Pears RJ, Pratchett MS, Skirving WJ, Stella JS, Torda G (2018) Global warming transforms coral reef assemblages. Nature 556:492-496. https://doi.org/10.1038/s41586-018-0041-2

Ibrahim N, Mohamed M, Basheer A, Ismail H, Nistharan F, Schmidt A, Naeem R, Abdulla A, and Grimsditch G (2017) Status of Coral Bleaching in the Maldives in 2016. Marine Research Centre, Malé, Maldives. https://portals.iucn.org/library/sites/ library/files/documents/2017-025.pdf

Kohler KE, Gill SM (2006) Coral Point Count with Excel extensions (CPCe): A Visual Basic program for the determination of coral and substrate coverage using random point count methodology. Computers \& Geosciences 32(9):1259-1269. https://doi.org/10. 1016/j.cageo.2005.11.009

McClanahan TR (2017) Changes in coral sensitivity to thermal anomalies. Mar Ecol Prog Ser 570:71-85. https://doi.org/10. 3354/meps 12150

McCauley DJ, DeSalles PA, Young HS, Dunbar RB, Dirzo R, Mills MM, Micheli F (2012) From wing to wing: the persistence of long ecological interaction chains in less-disturbed ecosystems. Scientific Reports 2:409. https://doi.org/10.1038/srep00409

Obura DO, and Grimsditch GD (2009) Resilience assessment of coral reefs: assessment protocol for coral reefs, focusing on coral bleaching and thermal stress. IUCN

Obura D (2012) The diversity and biogeography of Western Indian Ocean reef-building corals. PLoS One 7(9):e45013. https://doi. org/10.1371/journalpone0045013

Oliver JK, Berkelmans R, Eakin CM (2018) Coral Bleaching in Space and Time. In: van Oppen M, Lough J (eds) Coral Bleaching. Ecological Studies (Analysis and Synthesis), 233. Springer, Cham. https://doi.org/10.1007/978-3-319-75393-5_3

Mumby PJ, Hastings A, Edwards HJ (2007) Thresholds and the resilience of Caribbean coral reefs. Nature 450(7166):98-101. https://doi.org/10.1038/nature06252

NASA Goddard Space Flight Center, Ocean Ecology Laboratory, Ocean Biology Processing Group. Moderate-resolution Imaging Spectroradiometer (MODIS) Aqua Chlorophyll Data; 2014 Reprocessing. NASA OB.DAAC, Greenbelt, MD, USA. https://doi.org/10.5067/aqua/modis/13m/chl/2

NOAA Coral Reef Watch (2013) updated daily. NOAA Coral Reef Watch Daily Global 5-km Satellite Coral Bleaching SST Anomaly and Degree Heating Week Products, June $3^{\text {rd }} 2013$ May $31^{\text {st }}$ 2017. College Park, Maryland, USA: NOAA Coral Reef Watch.. http://coralreefwatch.noaa.gov/satellite/hdf/index. php] Dataset accessed 2017-06-01
Penin L (2013) Response of coral assemblages to thermal stress: are bleaching intensity and spatial patterns consistent between events? Environmental Monitoring and Assessment 185(6):5031-5042

Perry CT, Morgan KM (2017a) Bleaching drives collapse in reef carbonate budgets and reef growth potential on southern Maldives reefs. Scientific Reports 7:40581

Perry CT, Morgan KM (2017b) Post-bleaching coral community change on southern Maldivian reefs: is there potential for rapid recovery? Coral Reefs 36(4):1189-1194

Perry CT, Alvarez-Filip L, Graham NAJ, Mumby PJ, Wilson SK, Kench PS, Manzello DP, Morgan KM, Slangen ABA, Thomson DP, Januchowski-Hartley F, Smithers SG, Steneck RS, Carlton R, Edinger EN, Enochs IC, Estrada-Saldívar N, Haywood MDE, Kolodziej G, Murphy GN, Pérez-Cervantes E, Suchley A, Valentino L, Boenish R, Wilson M, Macdonald C (2018) Loss of coral reef growth capacity to track future increases in sea level. Nature 558(7710):396-400. https://doi.org/10.1038/s41586-0180194-Z

Perry CT, Murphy GN, Graham NAJ, Wilson SK, JanuchowskiHartley FA, East HK (2015) Remote coral reefs can sustain high growth potential and may match future sea-level trends. Scientific Reports 5:18289

Pinheiro J, Bates D, Deb-Roy S, Sarkar D and R Core Team (2018) nlme: Linear and Nonlinear Mixed Effects Models. $\mathrm{R}$ package version 3.1-137. https://svn.r-project.org/Rpackages/trunk/nlme

Pratchett MS, Graham NAJ, Sheppard CRC, Mayes B (2010) Are infestations of Cymo melanodactylus killing Acropora cytherea in the Chagos Archipelago? Coral Reefs 29:941

Pratchett MS, Pisapia C, Sheppard CRC (2013) Background mortality rates for recovering populations of Acropora cytherea in the Chagos Archipelago, central Indian Ocean. Marine environmental research 86:29-34

Price ARG, Harris A, McGowen A, Venkatachalam AJ, Shepperd CRC (2009) Chagos feels the pinch: assessment of holothurian (sea cucumber) abundance, illegal harvesting and conservation prospects in British Indian Ocean Territory. Aquatic Conservation 20(1):117-126

R Core Team (2017) R: a language and environment for statistical computing. https://www.R-project.org/

Riegl B, Piller WE (2003) Possible refugia for reefs in times of environmental stress. International Journal of Earth Sciences 92:520-531

Roche RC, Williams GJ, Turner JR (2018) Towards Developing a Mechanistic Understanding of Coral Reef Resilience to Thermal Stress Across Multiple Scales. Current Climate Change Reports 4:51-64

Rowan R (2004) Coral bleaching: thermal adaptation in reef coral symbionts. Nature 430(7001):742

Rowlands G, Purkis S, Riegl B, Metsamaa L, Bruckner A, Renaud P (2012) Satellite imaging coral reef resilience at regional scale. A case-study from Saudi Arabia. Mar Pollut Bull 64:1222-1237

Safaie A, Silbiger NJ, McClanahan TR, Pawlak G, Barshis DJ, Hench JL, Rogers JS, Williams GJ, Davis KA (2018) High frequency temperature variability reduces the risk of coral bleaching. Nature Communications 9:1671. https://doi.org/10.1038/s41467018-04074-2

Samoilys M, Roche R, Koldewey H, Turner J (2018) Patterns in reef fish assemblages: Insights from the Chagos Archipelago. PLOS ONE 13:e0191448. https://doi.org/10.1371/journal.pone. 0191448

Shaver EC, Burkepile DE, Silliman BR (2018) Local management actions can increase coral resilience to thermally-induced bleaching. Nature Ecology \& Evolution 2(7):1075-1079. https://doi.org/10.1038/s41559-018-0589-0\%5d 
Sheppard CRC (1999) Coral decline and weather patterns over 20years in the Chagos Archipelago, central Indian Ocean. Ambio $28: 472-478$

Sheppard CRC (2002) Island elevations, reef condition and sea level rise in atolls of Chagos, British Indian Ocean Territory. In: Linden O, Souter D, Wilhelmsson D, Obura D (eds) Cordio Report 2002. Kalmar University, Kalmar, Sweden, pp 202-211

Sheppard CRC (2009) Large temperature plunges recorded by data loggers at different depths on an Indian Ocean atoll: comparison with satellite data and relevance to coral refuges. Coral Reefs 28:399-403

Sheppard CRC, Ateweberhan M, Bowen BW, Carr P, Chen CA, Clubbe C, Craig MT, Ebinghaus R, Eble J, Fitzsimmons N, Gaither MR, Gan CH, Gollock M, Guzman N, Graham NAJ, Harris A, Jones R, Keshavmurthy S, Koldewey H, Lundin CG, Mortimer JA, Obura D, Pfeiffer M, Price ARG, Purkis S, Raines P, Readman JW, Riegl B, Rogers A, Schleyer M, Seaward MRD, Sheppard ALS, Tamelander J, Turner JR, Visram S, Vogler C, Vogt S, Wolschke H, Yang JMC, Yang SY, Yesson C (2012) Reefs and islands of the Chagos Archipelago, Indian Ocean: why it is the world's largest no-take marine protected area. Aquatic Conservation: Marine and Freshwater Ecosystems 22:232-261

Sheppard CRC, Sheppard A, Mogg A, Bayley D, Dempsey AC, Roche R, Turner J, Purkis S (2017) Coral bleaching and mortality in the Chagos Archipelago. Atoll Research Bulletin 613:1-26
Suggett DJ, Smith DJ (2011) Interpreting the sign of coral bleaching as friend vs. foe. Global Change Biology 17(1):45-55

Turner JA, Thomson DP, Cresswell AK, Trapon M, Babcock RC (2018) Depth-related patterns in coral recruitment across a shallow to mesophotic gradient. Coral Reefs 37:711-722

Veron JEN, Hoegh-Guldberg O, Lenton TM, Obura DO, Pearce-Kelly P, Sheppard CR, Spalding M, Stafford-Smith MG, Rogers AD (2009) The coral reef crisis: The critical importance of $<350$ ppm CO 2. Marine Pollution Bulletin 58(10):1428-1436

Weis VM (2008) Cellular mechanisms of cnidarian bleaching: stress causes the collapse of symbiosis. J Exp Biol 211(19):3059-3066. https://doi.org/10.1242/jeb.009597

Welle PD, Small MJ, Doney SC, Azevedo IL (2017) Estimating the effect of multiple environmental stressors on coral bleaching and mortality. PLoS ONE 12(5):e0175018. https://doi.org/10.1371/ journal.pone.0175018

Wickham H (2016) ggplot2: Elegant Graphics for Data Analysis. Springer-Verlag, New York

Yeager LA, Marchand P, Gill DA, Baum JK, McPherson JM (2017) Marine Socio-Environmental Covariates: Queryable global layers of environmental and anthropogenic variables for marine ecosystem studies. Ecology 98(7):1976. https://doi.org/10.1002/ ecy. 1884

Publisher's Note Springer Nature remains neutral with regard to jurisdictional claims in published maps and institutional affiliations. 